\title{
Educational Status, Leisure-Time Physical Activity and Body Composition in Serbian Adult Population
}

\author{
*Filip KUKIĆ ${ }^{1}$, Milivoj DOPSAJ ${ }^{1,2}$, Marina Đorđević NIKIĆ ${ }^{1}$, Nenad \\ KOROPANOVSKI ${ }^{3}$, Miloš MAKSIMOVIĆ ${ }^{4}$, Fadilj EMINOVIĆ ${ }^{5}$, Violeta DOPSAJ ${ }^{6}$
}

1. Department of Analysis and Diagnosis in Sport, Faculty of Sport and Physical Education, University of Belgrade, Belgrade, Serbia

2. Institute of Sport, Tourism and Service, South Ural State University, Chelyabinsk, Russia

3. Department of Police Sciences, University of Criminal Investigation and Police Studies, Belgrade, Serbia

4. Institute of Hygiene and Medical Ecology, Faculty of Medicine, University of Belgrade, Serbia

5. Department of Motor Impairments, Faculty of Special Education and Rehabilitation, University of Belgrade, Belgrade, Serbia

6. Department of Medical Biochemistry, Faculty of Pharmacy, University of Belgrade, Belgrade, Serbia

*Corresponding Author: Email: filip.kukic@gmail.com

(Received 14 May 2019; accepted 27 May 2019)

\section{Dear Editor-in-Chief}

Leisure time physical activity (LTPA) is fundamental to people's health, their proper functioning and quality of life. Increased LTPA is associated with better body composition $(1,2)$. More importantly, LTPA is negatively associated with all-cause mortality and positively related to increased life expectancy (3). Lower levels of physical activity followed by an increased level of abdominal body fatness increases the proclivity to cardiovascular diseases, obesity, and the metabolic syndrome (4). This is important, as obesity is a leading public health problem in both developed and developing countries.

The European Prospective Investigation into Cancer and Nutrition study showed that the body mass index (BMI) was significantly lower in people with higher education (5). Therefore, this study aimed to investigate if the weekly frequency and volume of LTPA (F-LTPA and V-LTPA) and body composition of female and male adults were affected by educational status.

The sample included 1561 healthy Serbian adults whose data was collected from January to December 2018 (Table 1).
All subjects were informed about the purpose of the study, and their data were collected and analyzed only upon their written consent. The research was carried out in accordance with the conditions of the declaration of Helsinki, recommendations guiding physicians in biomedical research involving human subjects, and with the ethical approval Number 484-2 of the ethical board of the University of Belgrade Faculty of Sport and Physical Education.

The level of education and the LTPA were collected using the International Physical Activity Questionnaire (IPAQ), appended by the question about the highest level of completed education. The subjects were recruited randomly from a selected choice of different universities, companies and government organizations. The subjects were stratified into working females and males with university degree, working females and males with no university degree, and female and male students. A bioelectrical impedance analysis was used to measure body composition. The BMI was utilized as a general indicator of the nutritional status. The PBF and visceral fat area (VFA) were chosen as indicators of body fatness. 
A fat-free mass index (FFMI) was chosen as an indicator of body size-independent lean body mass (6).
The multivariate analysis of variance (MANOVA) with the least significant difference adjustment and significance level of $P<0.05$ was used to analyze the differences between the groups.

Table 1: Descriptive statistics for the subsample size $(\mathrm{N})$ mean and standard deviation (SD) for female and male subjects relative to their educational level.

\begin{tabular}{|c|c|c|c|c|c|c|c|}
\hline \multirow[t]{2}{*}{ Gender } & \multirow[t]{2}{*}{ Variables } & \multicolumn{2}{|c|}{ University } & \multicolumn{2}{|c|}{ No university } & \multicolumn{2}{|r|}{ Students } \\
\hline & & $\boldsymbol{N}$ & Mean $\pm S D$ & $\mathbf{N}$ & Mean $\pm S D$ & $\mathbf{N}$ & Mean $\pm S D$ \\
\hline \multirow[t]{7}{*}{ Female } & Age $(y r)$ & 348 & $34.56 \pm 11.20$ & 157 & $40.00 \pm 12.64$ & 370 & $23.01 \pm 2.62$ \\
\hline & F-LTPA (trainings/week) & & $2.34 \pm 2.43$ & & $2.15 \pm 2.29$ & & $2.19 \pm 2.37$ \\
\hline & V-LTPA (min/week) & & $158.20 \pm 194.27$ & & $126.34 \pm 156.18$ & & $127.95 \pm 162.96$ \\
\hline & BMI $\left(\mathrm{kg} / \mathrm{m}^{2}\right)$ & & $23.64 \pm 5.08$ & & $25.73 \pm 5.87$ & & $21.83 \pm 3.30$ \\
\hline & $\operatorname{PBF}(\%)$ & & $28.15 \pm 9.25$ & & $31.53 \pm 9.00$ & & $25.33 \pm 7.05$ \\
\hline & $\operatorname{VFA}\left(\mathrm{cm}^{2}\right)$ & & $75.67 \pm 46.78$ & & $96.28 \pm 49.95$ & & $46.51 \pm 25.41$ \\
\hline & FFMI $\left(\mathrm{kg} / \mathrm{m}^{2}\right)$ & & $16.24 \pm 1.24$ & & $17.01 \pm 1.88$ & & $16.17 \pm 1.89$ \\
\hline \multirow[t]{8}{*}{ Male } & Age & 297 & $38.39 \pm 12.16$ & 127 & $33.86 \pm 13.60$ & 262 & $23.64 \pm 2.95$ \\
\hline & F-LTPA (trainings/week) & & $2.94 \pm 2.40$ & & $2.23 \pm 2.31$ & & $4.68 \pm 3.66$ \\
\hline & V-LTPA (min/week) & & $177.01 \pm 187.98$ & & $146.62 \pm 194.24$ & & $328.10 \pm 316.47$ \\
\hline & $\mathrm{BH}(\mathrm{cm})$ & & $182.69 \pm 7.09$ & & $182.11 \pm 7.35$ & & $183.20 \pm 7.01$ \\
\hline & BMI $\left(\mathrm{kg} / \mathrm{m}^{2}\right)$ & & $26.98 \pm 4.77$ & & $27.07 \pm 5.31$ & & $24.91 \pm 3.27$ \\
\hline & $\operatorname{PBF}(\%)$ & & $19.75 \pm 8.36$ & & $20.33 \pm 8.12$ & & $15.05 \pm 6.92$ \\
\hline & VFA $\left(\mathrm{cm}^{2}\right)$ & & $103.88 \pm 46.77$ & & $99.30 \pm 48.43$ & & $65.67 \pm 32.58$ \\
\hline & FFMI $\left(\mathrm{kg} / \mathrm{m}^{2}\right)$ & & $21.32 \pm 1.96$ & & $21.23 \pm 2.45$ & & $21.01 \pm 1.84$ \\
\hline
\end{tabular}

Error! Reference source not found.The FLTPA and V-LTPA and body composition were affected by educational status (Table 2). The FLTPA was unaffected by the educational status in females. Males with university degree were more frequently active than the ones without it. Female students had lower V-LTPA than the working females. Male students had higher V-LTPA than working males. Working females without university degree had higher BMI, percent of body fat $(\mathrm{PBF})$, and VFA than the ones with university degree. Working males had similar body composition while being fatter than students did.

Recently it was found that the frequency of 3-5 trainings per week may be sufficient for the maintenance of fat and muscle mass, while for further modifications, the volume of more than 300 minutes per week may be more effective (1). The present study additionally indicate that people with higher level of education tend to be more physically active but also possess lower levels of body fatness.

People should be encouraged to pursue higher education as it may increase awareness about the benefits of physical activity and body composition for health and ultimately improve public health.

\section{Acknowledgements}

The paper is a part of the project III47015, funded by the Ministry of Education, Science and Technological Development of the Republic of Serbia - Scientific Projects 2014-2019.

\section{Conflict of interests}

The authors declare that there is no conflict of interests. 
Kukić et al.: Educational Status, Leisure-Time Physical Activity and ...

Table 2: The least significant difference analysis between the groups relative to educational level and gender

\begin{tabular}{|c|c|c|c|c|c|}
\hline \multirow{3}{*}{$\begin{array}{l}\text { Variables } \\
\text { F-LTPA (train- }\end{array}$} & \multicolumn{2}{|c|}{ Dependent variable } & \multicolumn{3}{|c|}{ Mean differences } \\
\hline & & & Whole sample & Female & Male \\
\hline & University & No university & $0.43^{*}$ & .19 & $0.71 *$ \\
\hline \multirow[t]{2}{*}{ ings/week) } & & Students & $-0.61 * *$ & .15 & $-1.74 * *$ \\
\hline & No university & Students & $-1.03^{* *}$ & -.03 & $-2.45^{* *}$ \\
\hline \multirow{3}{*}{$\begin{array}{l}\text { V-LTPA } \\
\text { (min/week) }\end{array}$} & University & No university & $31.46^{*}$ & 31.86 & 30.38 \\
\hline & & Students & $-44.13 * *$ & $30.25^{*}$ & $-151 *$ \\
\hline & No university & Students & $-75.59 * *$ & -1.61 & $-181.47^{*}$ \\
\hline \multirow[t]{3}{*}{ BMI $\left(\mathrm{kg} / \mathrm{m}^{2}\right)$} & University & No university & $-1.14 *$ & $-2.09 * *$ & -.08 \\
\hline & & Students & $2.08^{* *}$ & $1.81 * *$ & $2.08^{* *}$ \\
\hline & No university & Students & $3.21 * *$ & $3.89 * *$ & $2.16^{* *}$ \\
\hline \multirow[t]{3}{*}{$\mathrm{PBF}(\%)$} & University & No university & $-2.21 *$ & $-3.38^{* *}$ & -.58 \\
\hline & & Students & $3.22 * *$ & $2.83^{* *}$ & $4.70^{* *}$ \\
\hline & No university & Students & $5.44 * *$ & $6.21 * *$ & $5.28^{* *}$ \\
\hline \multirow[t]{3}{*}{ VFA $\left(\mathrm{cm}^{2}\right)$} & University & No university & $-8.99 *$ & $-20.61 * *$ & 4.58 \\
\hline & & Students & $34.20 * *$ & $29.16^{* *}$ & $38.20 * *$ \\
\hline & No university & Students & $43.19 * *$ & $49.77 * *$ & $33.62 * *$ \\
\hline \multirow[t]{3}{*}{ FFMI $\left(\mathrm{kg} / \mathrm{m}^{2}\right)$} & University & No university & -.20 & $-.77 *$ & .08 \\
\hline & & Students & $.66^{* *}$ & .07 & .31 \\
\hline & No university & Students & $.86^{*}$ & $.84^{*}$ & .22 \\
\hline
\end{tabular}

$*$ Significant at $P<0.05,{ }^{* *}$ significant at $P<0.001$

\section{References}

1. Vuković M, Kukić F, Čvorović A, Janković D, Prćić I, Dopsaj M (2019). Relations between frequency and volume of leisure-time physical activity and body composition in police officers. Res Q Exerc Sport, 10:1-8.

2. Kukić F, Todorović N, Cvijanović N (2019). Effects of a 6-week controlled exercise program and semi-controlled diet on body fat and skeletal muscle mass in adults. Human Sport Medicine, 19 (1): 7-14.

3. Fishman EI, Steeves JA, Zipunnikov V, Koster A, Berrigan D, Harris TA, Murphy R (2016). Association between objectively measured physical activity and mortality in NHANES. Med Sci Sports Exerc, 48 (7):1303-1311.

4. Gleeson M, Bishop NC, Stensel DJ, Lindley MR, Mastana SS, Nimmo MA (2011). The antiinflammatory effects of exercise: mechanisms and implications for the prevention and treatment of disease. Nat Rev Immunol, 11 (9):607-15.

5. Hermann S, Rohrmann S, Linseisen J, et al (2011). The association of education with body mass index and waist circumference in the EPIC-PANACEA study. BMC Public Health. 11 (1):169-181.

6. Kukic F, Dopsaj M, Dawes J, Orr R, Cvorovic A (2018). Use of human body morphology as an indicator of physical fitness: Implications for police officers. Int J Morphol, 36 (4):14071412. 